\title{
Growth characteristics of natural and planted Dahurian larch in northeast China
}

\author{
Bingrui Jia ${ }^{1}$ and Guangsheng Zhou $^{2}$ \\ ${ }^{1}$ State Key Laboratory of Vegetation and Environmental Change, Institute of Botany, \\ Chinese Academy of Sciences, Beijing 100093, China \\ ${ }^{2}$ Chinese Academy of Meteorological Sciences, Beijing 100081, China \\ Correspondence: Bingrui Jia (jiabingrui@ibcas.ac.cn) and Guangsheng Zhou (gszhou@ibcas.ac.cn) \\ Received: 31 August 2017 - Discussion started: 12 October 2017 \\ Revised: 26 February 2018 - Accepted: 19 March 2018 - Published: 27 April 2018
}

\begin{abstract}
Dahurian larch (Larix gmelinii Rupr.) is the dominant species in both natural and planted forests in northeast China, which is situated in the southernmost part of the global boreal forest biome and is undergoing great climatically induced changes. Published studies (1965-2015) on tree above-ground growth of Dahurian larch forests in northeast China were collected in this study and critically reviewed, and a comprehensive growth data set was developed from 122 sites, which are distributed between 40.85 and $53.47^{\circ} \mathrm{N}$ in latitude, between 118.20 and $133.70^{\circ} \mathrm{E}$ in longitude and between 130 and $1260 \mathrm{~m}$ in altitude. The data set is composed of 743 entries and includes growth data (mean tree height, mean diameter at breast height (DBH), mean tree volume and/or stand volume) and associated information, i.e., geographical location (latitude, longitude, altitude, aspect and slope), climate (mean annual temperature (MAT) and mean annual precipitation (MAP)), stand description (origin, stand age, stand density and canopy density) and sample regime (observation year, plot area and plot number). It provides a quantitative reference for plantation management practices and boreal forest growth prediction under future climate change. The data set is freely available for noncommercial scientific applications, and the DOI for the data is https://doi.org/10.1594/PANGAEA.880984.
\end{abstract}

\section{Introduction}

Boreal forests, the second largest biome in the world, cover about one-third of the Earth's forest area (Achard et al., 2006; Keenan et al., 2015). Dahurian larch is a dominant tree species in Chinese boreal forest, which is distributed primarily in northeast China. Dahurian larch forest is also the predominant timber source in China, occupying $55 \%$ of Chinese boreal forest area and accounting for $75 \%$ of Chinese boreal forest volume (Xu, 1998; Zhou et al., 2002). Dahurian larch forest is situated in the southernmost part of the global boreal forest biome (Shugart et al., 1992) and is undergoing great climatically induced changes. Thus understanding the growth characteristics of Dahurian larch forest in China is of critical need for management and prediction under future climate change.

With the increased greenhouse effect and climate warming in recent years, forest carbon sink has been paid more and more attention by the world (Bastin et al., 2017). Forestation is the main measure to offset the greenhouse gas emission and increase carbon sink (Fang et al., 2001). China has the largest area of forest plantations in the world, approximately 79 million ha or one-quarter of the world's total (FAO, 2015; Payn et al., 2015). Forest cover showed an increasing trend through reforestation in northeast China (Achard et al., 2006). Dahurian larch is an important fast-growing and coldtolerant tree species used in forestation in northeast China (Yang, 2009). Dahurian larch is usually planted after fires or logging. The growth rates of Dahurian larch plantations are important indexes in the assessment of forest recovery processes and carbon sequestration potentials, which could supply strategies for post-fire or post-harvest management (Huang, 2011). The data set can provide a basis for evaluating and predicting carbon sequestration and the potential of forestation activities. 
Table 1. Variable information in the data set, available at https://doi.org/10.1594/PANGAEA.880984. N/A refers to values that are not applicable.

\begin{tabular}{|c|c|c|c|c|}
\hline Column code & Definition & Unit & Number & Range \\
\hline ID & Unique identification number of each record & N/A & 743 & $1-743$ \\
\hline Province & Province location of study site & N/A & 4 & N/A \\
\hline Study site & Locality name of study site & N/A & 122 & N/A \\
\hline Latitude & Latitude of study site & $\circ$ & 743 & $40.85-53.47$ \\
\hline Longitude & Longitude of study site & $\circ$ & 743 & $118.20-133.70$ \\
\hline Altitude & Altitude of study site & $\mathrm{m}$ & 743 & $130-1260$ \\
\hline Aspect & $\begin{array}{l}\text { Slope direction of study site, including flat slope, sunny slope } \\
\text { (south), half-sunny slope (west, southwest, southeast), shady } \\
\text { slope (north) and half-shady slope (east, northwest, northeast) }\end{array}$ & N/A & 289 & N/A \\
\hline Slope & Slope degree of study site & $\circ$ & 346 & $0-60$ \\
\hline Origin & Stand origin was classified into natural and planted forests & N/A & 743 & N/A \\
\hline MAT & $\begin{array}{l}\text { Mean annual temperature, from original study or other related } \\
\text { reference }\end{array}$ & ${ }^{\circ} \mathrm{C}$ & 743 & $-6.1-7.0$ \\
\hline MAP & $\begin{array}{l}\text { Mean annual precipitation, from original study or other related } \\
\text { reference }\end{array}$ & $\mathrm{mm}$ & 743 & $355-926$ \\
\hline Age & $\begin{array}{l}\text { Stand age, which is generally defined as age since germination } \\
\text { in natural forest and since planting in planted forest; stand age } \\
\text { is usually obtained from historical records or tree rings }\end{array}$ & years & 743 & $1-280$ \\
\hline Height & $\begin{array}{l}\text { Mean tree height; the estimated tree height data from the power } \\
\text { H-DBH equation were marked with }{ }^{\mathrm{E}} \text { in the data set }\end{array}$ & $\mathrm{m}$ & 708 & $0.24-29.4$ \\
\hline DBH & $\begin{array}{l}\text { Mean diameter at breast height; base diameter was only given } \\
\text { in some young forests and marked with }{ }^{\mathrm{B}} \text { in the data set }\end{array}$ & $\mathrm{cm}$ & 664 & $0.70-34.9$ \\
\hline$V_{\text {tree }}$ & $\begin{array}{l}\text { Mean tree volume; the estimated tree volume data from the two- } \\
\text { variable larch equation were marked with } \mathrm{E}_{\text {in }} \text { the data set }\end{array}$ & $10^{-3} \mathrm{~m}^{3} /$ tree & 663 & $0.04-936$ \\
\hline$V_{\text {stand }}$ & $\begin{array}{l}\text { Stand volume; the estimated stand volume data from the esti- } \\
\text { mated tree volume and stand density were marked with }{ }^{E} \text { in the } \\
\text { data set }\end{array}$ & $\mathrm{m}^{3} \mathrm{ha}^{-1}$ & 557 & $0.07-975$ \\
\hline \multirow[t]{2}{*}{ Density } & \multirow{2}{*}{$\begin{array}{l}\text { Stand density/canopy density; planting density was only given } \\
\text { in some studies and marked with }{ }^{P} \text { in the data set }\end{array}$} & trees ha ${ }^{-1}$ & 623 & $213-13275$ \\
\hline & & $\%$ & 139 & $0.2-1.0$ \\
\hline Area & Plot area & $\mathrm{m}^{2}$ & 378 & $50-10000$ \\
\hline Plot & Plot numbers, i.e., replications & N/A & 540 & $1-25$ \\
\hline Year & Investigation year & N/A & 500 & 1954-2014 \\
\hline Reference & $\begin{array}{l}\text { Data sources; sources used to supplement climate information } \\
\text { lacking in the original publications are denoted by asterisks in } \\
\text { the data set }\end{array}$ & N/A & 223 & 1965-2015 \\
\hline
\end{tabular}

Relating the easily measured variables (e.g., DBH, tree height) to other structural and functional characteristics, is the most common and reliable method for estimating forest biomass, net primary production and biogeochemical budgets (Luo, 1996; Fang et al., 2001). Synthesis studies mainly focused on larch biomass and net primary production with increasing samples in recent decade in northeast China, for example, $N=28$ (Luo, 1996), $N=17$ (Wang et al., 2001a), $N=18$ (Wang et al., 2001b; Zhou et al., 2002), $N=36$ (Wang et al., 2005), $N=83$ (Wang et al., 2008), $N=50$ (Zeng, 2015), $N=150$ (Zeng et al., 2017). However, large numbers of growth measurements (e.g., age, DBH, tree height, volume) have scarcely been studied systematically at the large scale. Therefore, a comprehensive growth data set $(N=743)$ of Dahurian larch in northeast China was developed in this paper.

\section{Data and methods}

\subsection{Research origin descriptors}

1. The identity is as follows: "Growth data set of natural and planted Dahurian larch in northeast China, version $1.0 "$ ".

2. The originators are as given below:

Bingrui Jia, State Key Laboratory of Vegetation and Environmental Change, Institute of Botany, Chinese Academy of Sciences, Beijing 100093, China;

Guangsheng Zhou, Chinese Academy of Meteorological Sciences, Beijing 100081, China. 


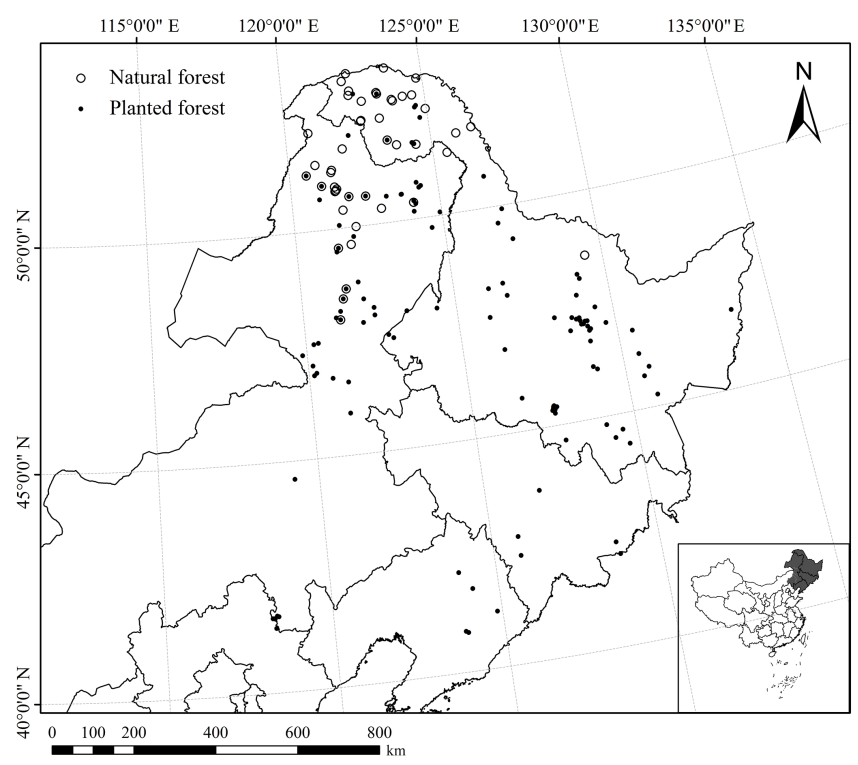

Figure 1. Study sites of Dahurian larch across northeastern China, including Heilongjiang, Liaoning and Jilin provinces and the eastern part of the Inner Mongolia Autonomous Region. Open circles represent natural forests and dots represent planted forests.

3. The period of study is from January 1965 to December 2015.

4. Objectives include conducting a complete literature review of published studies on age, DBH, tree height and/or volume in natural and planted Dahurian larch forests in order to construct a growth data set. The data set can be used to analyze growth characteristics of Dahurian larch forests and assess their potential productivity in future climate warming.

\subsection{Site description}

1. Site type. Data were derived from 122 study sites in northeastern China. This region includes Heilongjiang, Liaoning and Jilin provinces and the eastern part of the Inner Mongolia Autonomous Region (Fig. 1).

2. Habitat. Dahurian larch forest is naturally distributed in the Great Xing' an Mountains of northeastern China. Dahurian larch is usually planted in barren hills, postfire areas or post-harvest areas in northeast China.

3. Climate. The climate in northeast China is controlled by the high latitude East Asian monsoon, changing from cool temperate to temperate zones from north to south, and from semi-arid to humid zones from west to east. Mean annual temperature (MAT) for these sites ranged from -6.1 to $7.0^{\circ} \mathrm{C}$, and mean annual precipitation (MAP) ranged from 355 to $926 \mathrm{~mm}$.

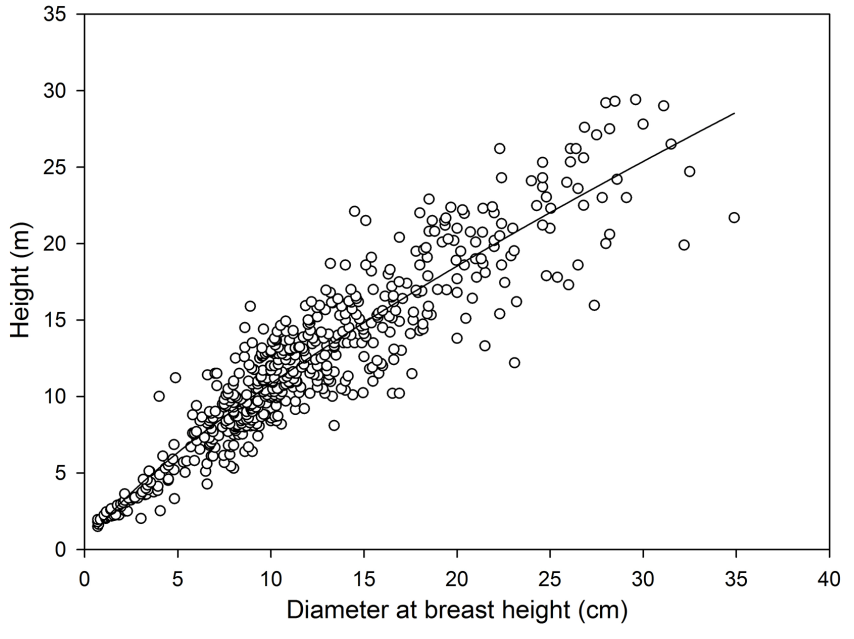

Figure 2. Relationship between mean tree height and diameter at breast height in the data set.

\subsection{Data sources}

Published studies (1965-2015) were collected from available online full-text databases, including China Knowledge Resource Integrated Database (http://www.cnki.net/, last access: 14 April 2018), China Science and Technology Journal Database (http://www.cqvip.com/, last access: 14 April 2018), Wanfang Data Knowledge Service Platform (http: //www.wanfangdata.com/, last access: 14 April 2018), ScienceDirect (http://www.sciencedirect.com/, last access: 14 April 2018), ISI Web of Science (http://isiknowledge.com/, last access: 14 April 2018) and Springer Link (http://link. springer.com/, last access: 14 April 2018). The different combinations of the terms "Dahurian larch" (or "Larix gmelinii") with "height", "diameter at breast height (or DBH)", "tree volume" or "stand volume" were searched in full text. Meanwhile, we also looked up related books (e.g., Ma, 1992; Wang, 1992; Zhou, 1994; Yang, 2009). We attempted to compile a complete growth data set of natural and planted Dahurian larch in the northeastern part of China (between 40.85 and $53.47^{\circ} \mathrm{N}$; between 118.20 and $133.70^{\circ} \mathrm{E}$ ).

\subsection{Data collection criteria}

A critical review of the literature collected from the abovementioned sources was conducted to obtain reliable growth data using the following criteria.

1. Scope. The objective of this study was to provide the data for understanding growth characteristics of Dahurian larch natural forests (pure Dahurian larch or its proportion more than $50 \%$ ) and monoculture plantations. Forest stands included in the data set were restricted to those not recently disturbed by logging, fires or insect pests. Additionally, the following small numbers of special types were excluded: (i) Dahurian 
larch afforestation in wetland ( $\mathrm{Li}$ et al., 1985; Song and Li, 1990; Huang, 2011; Cui et al., 2013), pastureland (Duan, 2005) or abandoned mine land (Yang et al., 2013); (ii) hybrid test between Dahurian larch and other larch (Deng et al., 2010; Zhang et al., 2005) and (iii) low-yield stands in hard environments (Wang et al., 1979, 1991).

2. Study design and sampling. DBH and tree height were averaged from the measurement values of all trees in plots or with a random or systematic sampling method. The tree regeneration layer, generally below $5 \mathrm{~cm}$ in DBH or $1.3 \mathrm{~m}$ in height, was neglected in the sampled plots. The stem volume of individual tree was computed from felled wood samples or local tree volume equations. The stand volume was usually calculated by multiplying the mean individual volume by the stand density. Besides the growth data (i.e., DBH, height and/or volume), the necessary information is provided in the original sources, e.g., stand age, stand origin and study site.

3. Quality control. The data quality has been carefully reviewed by the authors. Data have undergone substantial checking, for example, a cross-check for relevant information from different sources and preliminary correlation analysis among growth variables.

Consequently, 743 records that met the above criteria were selected to develop a comprehensive growth data set of Dahurian larch in China. The data set includes growth characteristics of Dahurian larch (i.e., mean tree height (m), mean DBH $(\mathrm{cm})$, mean tree volume $\left(10^{-3} \mathrm{~m}^{3}\right)$ and/or stand volume $\left.\left(\mathrm{m}^{3} \mathrm{ha}^{-1}\right)\right)$. In addition, associated information was included, if available in original sources or ascertainable from other relevant literature, i.e., geographical location (province location and locality name of study site, latitude $\left(^{\circ}\right)$, longitude $\left({ }^{\circ}\right)$, altitude $(\mathrm{m})$, aspect and slope $\left({ }^{\circ}\right)$ ), stand description (origin, stand age (years), stand density (trees ha ${ }^{-1}$ ) and canopy density), climate (mean annual temperature (MAT, ${ }^{\circ} \mathrm{C}$ ) and mean annual precipitation (MAP, $\mathrm{mm}$ )) and sample regime (observing year, plot size and number). Table 1 lists these variables and their definitions, units, number and range.

\section{Data availability}

The data set developed in this paper is freely available for noncommercial scientific applications, and the DOI for the data is https://doi.org/10.1594/PANGAEA.880984.

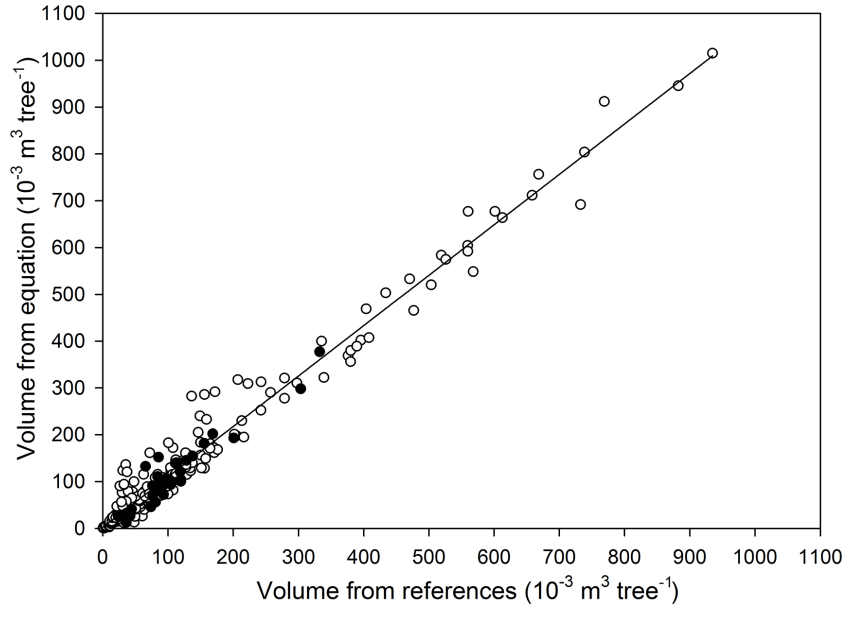

Figure 3. Comparison of available tree volume from references with simulated values from the two-variable tree volume equation $\left(V_{\text {tree }}=0.000050168241 \mathrm{DBH}^{1.7582894} H^{1.1496653}\right)$. Open circles $(N=284)$ show that both tree height $(H)$ and diameter at breast height $(\mathrm{DBH})$ are available in the references; solid circles $(N=37)$ show that only DBH is available in the references and $\mathrm{H}$ is estimated using the H-DBH model from Fig. 2.

\section{Data estimates and evaluation}

\subsection{Geographical location}

Google Earth (Version: 7.1.8.3036) was used to estimate latitude, longitude and/or altitude when the geographic coordinates were unavailable in original sources.

\subsection{Tree and stand volume}

The missing tree and stand volumes were estimated with the available information (mean DBH, mean tree height and stand density). The stem volume of individual trees was calculated using the larch equation for northeast China ( $V_{\text {tree }}=$ $\left.0.000050168241 \mathrm{DBH}^{1.7582894} H^{1.1496653}\right)$, the best method recommended by the national standard of China tree volume tables (LY 208-77) (Agriculture and Forestry Ministry of China, 1978; Liu, 2017). Meanwhile, 557 available pairs of mean tree height and mean DBH in the data set were used to establish the $\mathrm{H}-\mathrm{DBH}$ correlation with a power function $\left(R^{2}=0.8943, P<0.001\right.$, see Fig. 2$)$. To calculate tree volume from only one known variable of $\mathrm{DBH}$, tree height was firstly calculated with the power H-DBH equation in Fig. 2. The estimated stand volume was determined by multiplying the estimated tree volume by the stand density.

The accuracy of the tree volume was assessed by comparing the extracted data from references with the calculated data from the above-mentioned two-variable tree volume equation (Fig. 3). The coefficient of determination $\left(R^{2}\right)$ was $0.9739(P<0.001)$ and the slope was 1.0767 . There- 
fore, we were confident in applying the larch volume equation to interpolate tree and stand volume data in this study.

Competing interests. The authors declare that they have no conflict of interest.

Acknowledgements. We would like to acknowledge many scientists and researchers whose field measurements made this work possible. Professor Weisheng Zeng and Frederic Achard are appreciated for their useful comments and suggestions. This research was supported by the National Key Research and Development Program of China (2017YFC0503906) and the China Special Fund for Meteorological Research in the Public Interest (GYHY201406034).

Edited by: Hannes Grobe

Reviewed by: Arunkumar Anbu Aravazhi and one anonymous referee

\section{References}

Achard, F., Mollicone, D., Stibig, H., Aksenov, D., Laestadius, L., Li, Z., Popatov, P., and Yaroshenko, A.: Areas of rapid forestcover change in boreal Eurasia, Forest Ecol. Manag., 237, 322334, https://doi.org/10.1016/j.foreco.2006.09.080, 2006.

Agriculture and Forestry Ministry of China: Tree Volume Tables (LY 208-77), Standard Press of China, Beijing, China, 1978 (in Chinese).

Bastin, J. F., Berrahmouni, N., Grainger, A., Maniatis, D., Mollicone, D., Moore, R., Patriarca, C., Picard, N., Sparrow, B., Abraham, E. M., Aloui, K., Atesoglu, A., Attore, F., Bassüllü, Ç., Bey, A., Garzuglia, M., García-Montero, L. G., Groot, N., Guerin, G., Laestadius, L., Lowe, A. J., Mamane, B., Marchi, G., Patterson, P., Rezende, M., Ricci, S., Salcedo, I., Diaz, A. S. P., Stolle, F., Surappaeva, V., and Castro, R.: The extent of forest in dryland biomes, Science, 356, 635-638, https://doi.org/10.1126/science.aam6527, 2017.

Cui, W., Mu, C. C., Lu, H. C., Bao, X., and Wang, B.: Effects of draining for forestation on carbon storage of wetland ecosystem in Daxing'an Mountains of northeastern China, J. Beijing For. Univ., 35, 28-36, https://doi.org/10.13332/j.10001522.2013.05.020, 2013 (in Chinese).

Deng, J. F., Zhang, H. G., Zhang, L., Guan, C. Y., and Zhang, L.: Genetic variation of 17-year-old hybrid larch and its superior family selection, J. Northeast For. Univ., 38, 8-11, https://doi.org/10.13759/j.cnki.dlxb.2010.01.017, 2010 (in Chinese).

Duan, W. B.: Suitable types of soils for main tree species of Shelterbelts on pastureland, Chin. J. Soil Sci., 36, 871-876, https://doi.org/10.3321/j.issn:0564-3945.2005.06.012, 2005 (in Chinese).

Fang, J., Chen, A., Peng, C., Zhao, S., Ci, L.: Changes in forest biomass carbon storage in China between 1949 and 1998, Science, 292, 2320-2322, https://doi.org/10.1126/science.1058629, 2001.
FAO: Global Forest Resources Assessment 2015, UN Food and Agriculture Organization, Rome, Italy, available at: http://www. fao.org/3/a-i4808e.pdf (last access: 8 October 2017), 2015.

Huang, D. Q.: Biomass and carbon storage estimation of Larix gmelinii, Thesis, available at: http://d.wanfangdata.com.cn/ Thesis/Y2026419 (last access: 8 October 2017), 2011 (in Chinese).

Keenan, R. J., Reams, G. A., Achard, F., de Freitas, J. V., Grainger, A., and Lindquist, E.: Dynamics of global forest area: Results from the FAO Global Forest Resources Assessment 2015, Forest Ecol. Manag., 352, 9-20, https://doi.org/10.1016/j.foreco.2015.06.014, 2015.

Li, J. C., Zhao, Y. Y., Gao, Y. Q., and Liu, G. L.: A preliminary analysis of changes in ecological factors after reforestation in swamp land, Sci. Silvae Sin., 21, 80-85, available at: http://www.linyekexue.net/CN/Y1985/V21/I1/80 (last access: 8 October 2017), 1985 (in Chinese).

Liu, Q. J.: Tree volume tables of China, China Forestry Publishing House, Beijing, China, 2017 (in Chinese).

Luo, T. X.: Patterns of net primary productivity for Chinese major forest types and their mathematical models, Thesis, available at: http://cdmd.cnki.com.cn/Article/CDMD-80061-2006113572. htm (last access: 8 October 2017), 1996 (in Chinese).

Ma, C. G.: Selection of optimum species and seed sources for plantations of larch, Beijing Agricultural university press, Beijing, China, 1992 (in Chinese).

Payn, T., Carnus, J. M., Freer-Smith, P., Kimberley, M., Kollert, W., Liu, S. R., Orazio, C., Rodriguez, L., Silva, L. N., and Wingfield, M. J.: Changes in planted forests and future global implications, Forest Ecol. Manag., 352, 57-67, https://doi.org/10.1016/j.foreco.2015.06.021, 2015.

Shugart, H. H., Leemans, R., and Bonan, G. B.: A system analysis of the global boreal forest, Cambridge University Press, Cambridge, 1-10, 1992.

Song, X. S. and Li, Y. M.: Study on the effect of improvement of fen land and afforestation of Larix gmelinii, Forestry Science and Technology, 6, 5-7, available at: http://www.cnki.com.cn/ Article/CJFDTotal-LYKT199006002.htm (last access: 8 October 2017), 1990 (in Chinese).

Wang, H. Q., Wu, J. C., Yang, W. B., Wang, S. T., and Song, C. J.: A research on management and utilization of "old man forest" of Larix gmelinii, Forestry Science and Technology, 16, 12-14, available at: http://www.cnki.com.cn/ Article/CJFDTOTAL-LYKJ199103003.htm (last access: 8 October 2017), 1991 (in Chinese).

Wang, W. J., Zu, Y. G., Wang, H. M., Matsuura, Y., Sasa, K., and Koike, T.: Plant biomass and productivity of Larix gmelinii forest ecosystems in Northeast China: intra- and interspecies comparison, Eurasian J. For. Res., 8, 21-41, available at: https://eprints.lib.hokudai.ac.jp/dspace/bitstream/2115/ 22188/1/8(1)P21-41.pdf (last access: 8 October 2017), 2005.

Wang, X. P., Fang, J. Y., and Zhu, B.: Forest biomass and rootshoot allocation in northeast China, Forest Ecol. Manag., 255, 4007-4020, https://doi.org/10.1016/j.foreco.2008.03.055, 2008.

Wang, Y. H., Zhou, G. S., and Jiang, Y. L.: Simulation of NPP and evaluation of ecosystem services of Larix gmelinii forest, Chin. J. Appl. Ecol., 12, 648-652, available at: http://www.cnki.com. cn/Article/CJFDTotal-YYSB200105001.htm (last access: 8 October 2017), 2001a (in Chinese). 
Wang, Y. H., Zhou, G. S., Jiang, Y. L., and Yang, Z. Y.: Estimating biomass and NPP of Larix forests using forest inventory data(FID), Acta Phytoecol. Sin., 25, 420-425, available at: http:// www.cnki.com.cn/Article/CJFDTOTAL-ZWSB200104006.htm (last access: 8 October 2017), 2001b (in Chinese).

Wang, Z.: Larch Forest in China, China Forestry Publishing House, Beijing, China, 73-150, 1992 (in Chinese).

Wang, Z., Xu, Z. B., Tan, Z. X., and Dai, H. C.: Ecological characteristics of Larix gmelinii grown in igneous rock in Aershan forest region, Sci. Silvae Sin., 4, 300-303, available at: http:// www.cnki.com.cn/Article/CJFDTOTAL-LYKE197904010.htm (last access: 8 October 2017), 1979 (in Chinese).

$\mathrm{Xu}, \mathrm{H} .:$ Forests in Daxinganling Mountains China, Science Press, Beijing, China, 22-53, 1998 (in Chinese).

Yang, C. P.: Study on the provenance of Dahurian larch, Science Press, Beijing, China, 2009 (in Chinese).

Yang, Y., Zhang, K., Cai, T. J., and Gu, J. F.: Effect of afforestation species on soil nutrient in dumping site of open coal mine in Daxing'an Mountain, J. Northeast For. Univ., 41, 54-58, https://doi.org/10.13759/j.cnki.dlxb.2013.09.028, 2013 (in Chinese).
Zeng, W. S.: Integrated individual tree biomass simultaneous equations for two larch species in northeastern and northern China, Scand. J. Forest Res., 30, 594-604, https://doi.org/10.1080/02827581.2015.1046481, 2015.

Zeng, W. S., Duo, H. R., Lei, X. D., Chen, X. Y., Wang, X. J., Pu, Y., and Zou, W. T.: Individual tree biomass equations and growth models sensitive to climate variables for Larix spp. in China, Eur. J. For. Res., 136, 233-249, https://doi.org/10.1007/s10342-0171024-9, 2017.

Zhang, H. G., Zhang, C. L., Lan, S. B., Kang, Y. K., and Pan, B. L.: The analysis and selection for families of hybrid larch, J. Nanjing For. Univ., 29, 69-72, https://doi.org/10.3969/j.issn.10002006.2005.03.017, 2005 (in Chinese).

Zhou, G. S., Wang, Y. H., Jiang, Y. L., and Yang, Z. Y.: Estimating biomass and net primary production from forest inventory data: a case study of China's Larix forests, Forest Ecol. Manag., 169, 149-157, https://doi.org/10.1016/s0378-1127(02)00305-5, 2002.

Zhou, X. F.: Long-Term Research on China's Forest Ecosystems, Northeast Forestry University Press, Harbin, China, 1994 (in Chinese) 